\title{
PENGARUH PERPUTARAN PERSEDIAAN VOUCHER SEV DALAM MENINGKATKAN LABA OPERASI PT. ELKOMINDO MITRA NUSANTARA BENGKULU
}

\author{
Herlin \\ Program Studi Akuntansi \\ Fakultas Ekonomi Universitas Dehasen Bengkulu
}

\begin{abstract}
ABSTRAK
Herlin; Persediaan merupakan bagian yang paling aktif dalam operasi perusahaan, yang secara terus-menerus dibeli atau diproduksi maupun dijual. Perputaran persediaan (inventory turnover) mengukur hubungan antara volume barang dagang yang dijual dengan jumlah persediaan yang dimiliki selama periode berjalan. Persediaan barang sangat penting artinya untuk setiap perusahaan, tanpa adanya persediaan yang mencukupi maka perusahaan tidak mampu memenuhi keinginan langganan, sehingga pengelolaan persediaan dalam perusahaan harus dilakukan secara efektif dan efisien. Penelitian ini bertujuan untuk menguji pengaruh perputaran persediaan barang dagangan dalam meningkatkan laba operasi PT. Elkomindo Mitra Nusantara Bengkulu. Sampel dalam penelitian ini adalah persediaan voucher SEV PT. Elkomindo Mitra Nusantara Bengkulu periode pengamatan selama 3 tahun. Perputaran persediaan selama tahun 2010, 2011 dan 2013 mengalami kenaikan untuk setiap tahunnya yang menunjukkan bahwa semakin tinggi perputaran persediaan makan laba operasi semakin meningkat, Ini membuktikan bahwa perputaran persediaan voucher SEV berpengaruh positif dalam meningkatkan laba operasi PT. Elkomindo Mitra Nusantara Bengkulu
\end{abstract}

\begin{abstract}
Herlin; Inventory is the most active part in the company's operations, which continually purchased or manufactured or sold. Turnover of inventory (inventory turnover) measures the relationship between the volume of merchandise sold by the amount of inventory on hand during the period. Inventory is very important for any company, in the absence of an adequate supply of the company is not able to meet customer desires, so that the company's inventory management should be carried out effectively and efficiently. This study aimed to examine the effect of the merchandise inventory turnover increase operating profit of PT. Mitra Nusantara Elkomindo Bengkulu. The sample in this study is the inventory voucher SEV PT. Mitra Nusantara Elkomindo Bengkulu observation period of 3 years. Inventory turnover during 2010, 2011 and 2013 has increased for each year showing that the higher the inventory turnover increased operating profit meal, this proves that the inventory turnover vouchers SEV gives positive effect in increasing the operating profit of PT. Mitra Nusantara Elkomindo Bengkulu
\end{abstract}

Key words: Inventory Turnover, Operating Profit

\section{PENDAHULUAN}

Persediaan merupakan bagian yang paling aktif dalam operasi perusahaan, yang secara terus-menerus dibeli atau diproduksi maupun dijual. Sumber daya perusahaan dapat diinvestasikan dalam barang yang dibeli atau diproduksi, akan tetapi kemajuan dalam teknologi informasi memungkinkan perusahaan untuk lebih efisien dalam mengelola tingkat persediaan perusahaan, sehingga perusahaan dihadapkan pada permasalahan yang semakin kompleks dan dinamis.

Perusahaan dituntut untuk inovatif dan mampu melakukan penyesuaian diri terhadap perubahan-perubahan yang terjadi. Salah satunya kemampuan menyimpan persediaan yang cukup untuk memenuhi kebutuhan pelanggannya dapat menjadi masalah yang sangat kompleks, kegagalan untuk memenuhi kebutuhan pelanggan bisa mengakibatkan menurunnya penjualan. Persoalan persediaan yang perlu dipecahkan adalah bagaimana perusahaan mampu memprediksi dengan tepat kebutuhan akan bahan baku dan juga barang jadi, bagaimana 
perusahaan dapat menyediakan persediaan tepat pada waktunya sesuai dengan jumlah yang diperlukan dan penyimpanan persediaan akan dapat meningkatkan risiko kerugian akibat penurunan harga, kerusakan atau perubahan pola pembelian pelanggan.

Persediaan dalam perusahaan dagang merupakan asset utama perusahaan. Persediaan yang ada dalam perusahaan dagang maupun perusahaan industri sangat menentukan aktivitas operasional perusahaan, kelebihan ataupun kekurangan persediaan barang merupakan gejala yang kurang baik, dimana kekurangan persediaan akan menyebabkan larinya konsumen sedangkan kelebihan persediaan dapat berakibat pemborosan, sehingga pengelolaan persediaan dalam perusahaan harus dilakukan secara efektif dan efisien. Manajemen perusahaan harus menetapkan perencanaan dan pengendalian yang baik terhadap persediaan, sehingga perputaran persediaan dalam perusahaan dalam berjalan dengan baik.

\section{Landasan Teori \\ Persediaan}

Menurut Stice (2011) persediaan adalah barang-barang yang dimilki oleh perusahaan dagang, baik berupa usaha grosir maupun ritel, ketika barang-barang tersebut telah dibeli dan ada kondisi siap untuk dijual. Alexandri (2009) menyatakan persediaan adalah suatu aktiva yang meliputi barang-barang milik perusahaan dengan maksud untuk dijual dalam suatu periode usaha tertentu atau persediaan bahan baku yang menunggu penggunaannya dalam pengerjaan atau proses produksi ataupun persediaan bahan baku yang menunggu penggunaannya dalam suatu proses produksi. Jenis persediaan perusahaan proses terdiri dari 3 (Ristono, 2009) meliputi persedian bahan baku, persedian barang dalam proses dan persediaan barang jadi. Bambang Riyanto (2001), menerangkan bahwa Inventory merupakan persediaan barang yang sesuai dalam perputaran, yang selalu dibeli dan dijual, yang tidak mengalami proses lebih lanjut di dalam perusahaan tersebut yang mengakibatkan perubahan bentuk dari barang yang bersangkutan.

Persediaan berpengaruh terhadap neraca maupun laporan laba rugi yang mempunyai peranan penting dalam menetukan hasil operasi perusahaan dalam suatu periode dan manajemen perusahaan yang efektif merupakan kunci keberhasilan operasi perusahaan. Manajemen berusaha untuk mempertahankan kuantitas dan jenis persediaan yang cukup untuk memenuhi permintaan konsumen tetapi disisi lain manajemen juga harus menghindari biaya penyimpanan yang terlalu tinggi dan pemeliharaan persediaan yang akan melambung. Jusup (2005) menyatakan bahwa persediaan memiliki dua karakteristik penting, yakni

1. Persediaan tersebut merupakan milik perusahaan

2. Persediaan tersebut siap dijual kepada konsumen

Menurut Gade dan Wasif (2005:97) persediaan barang dagang adalah "barang-barang yang dibeli baik tunai maupun kredit dengan tujuan untuk dijual kembali". Ikatan Akuntan Indonesia (2009:142), dalam buku Standar Akuntansi Keuangan adalah sebagai berikut: "Persediaan adalah asset yang tersedia untuk dijual dalam kegiatan usaha biasa, dalam proses produksi untuk penjualan tersebut, dalam bentuk bahan atau perlengkapan untuk digunakan dalam proses produksi atau pemberian jasa."

Munandar (2011) terdapat 3 metode pencatatan persediaan perpetual adalah metode First In First Out (FIFO), metode Last In First Out (LIFO) dan metode Rata-Rata. Perusahaan untuk menentukan angka harga pokok penjualan dan persediaan akhir dapat ditentukan dalam menggunakan metode penilaian persediaan (Libby at al, 2008) yaitu :

a. Metode persediaan perpetual

Metode persediaan perusahaan ini dicatat secara detail atau setiap saat, bila diperlukan data persediaan barang dapat diketahui tanpa melakukan perhitungan fisik atas barangbarang persediaan.

b. Metode persediaan periodik,

Metode ini perhitungan barang dilakukan pada akhir periode barang yang ada di dalam gudang, dimana perhitungan fisik persediaan untuk menentukan jumlah persediaan yang masih dimiliki. 


\section{Tingkat Perputaran Persediaan}

Adapun faktor- Faktor yang mempengaruhi perputaran persediaan meliputi tingkat penjualan, sifat teknis dan lamanya proses produksi serta daya tahan produk akhir. Tingkat perputaran persediaan (Inventory Turn Over) mempunyai efek langsung terhadap besar kecilnya model yang diinvestasikan ke dalam persediaan. Makin turn over persediaan maka jangka waktu modal yang diinvestasikan ke dalam persediaan makin pendek, sehingga untuk memenuhi volume penjualan tertentu membutuhkan jumlah modal yang lebih kecil dari pada Turn Over yang rendah.

Kuswadi (2008) menyatakan tingkat perputaran persediaan barang jadi diukur dengan rasio perputaran persediaan. Tingkat perputaran persediaan menunjukkan berapa kali persediaan barang dagangan dijual atau dibeli kembali. Semakin tinggi tingkat perputaran persediaan akan memperkecil resiko kerugian yang disebabkan penurunan harga atau perubahan selera konsumen dan bias menghemat biaya pemeliharaan persediaan. Soemarso (2004) Perputaran persediaan menunjukkan berapa kali (secara rata-rata) persediaan barang dijual dan diganti selama satu periode. Jumingan (2008) menjelaskan Perputaran Persediaan menunjukkan barang dijual dan diadakan kembali selama satu periode akuntansi. Perusahaan yang tidak hanya membeli dan menjual barang dagangan melainkan juga memproduksi barang dagangan, maka perusahaan ini akan mempunyai persediaan bahan mentah, barang dalam proses dan barang jadi pada akhir tahun. Munawir (2007) turn over persediaan adalah merupakan ratio atau jumlah harga pokok barng yang dijual dengan nilai rata-rata persediaan yang dimiliki oleh perusahaan.

Periode perputaran persediaan dapat digunakan untuk melihat apakah terdapat ketidakseimbangan, yang bisa saja menunjukkan kelebihan investasi dalam berbagai komponen tertentu persediaan. (Horne dan Wachowicz, 2009).

\section{Laba Operasi}

Pada umumnya laba merupakan selisih antara pendapatan yang diterima dengan biaya yang dikeluarkan dalam suatu periode akuntansi. Laba merupakan hasil akhir dari setiap perusahaan yang merupakan suatu informasi penting dalam laporan keuangan yang digunakan untuk menjadi pedoman dalam menentukan kebijakan dan pengambilan keputusan dalam perusahaan. Baridwan (2004) mendefinisikan laba adalah kenaikan modal (aktiva bersih) yang berasal dari transaksi sampingan atau transaksi yang jarang terjadi dari badan usaha dan dari semua transaksi atau kejadian lain yang mempengaruhi badan usaha selama satu periode kecuali yang termasuk dari pendapatan (revenue) atau investasi oleh pemilik. Wild, Subramanyam, dan Halsey (2005) mendefenisikan laba adalah Laba (earnings) atau laba bersih (net income) mengindikasikan profitabilitas perusahaan. Laba mencerminkan pengembalian kepada pemegang ekuitas untuk periode bersangkutan, sementara pos-pos dalam laporan merinci bagaimana laba didapat.

Stice, Stice, dan Skousen (2004) laba operasi mengukur kinerja operasi bisnis fundamental yang dilakukan oleh sebuah perusahaan dan didapat dari laba kotor dikurangi beban operasi. Laba operasi menunjukkan seberapa efisien dan efektif perusahaan melakukan aktivitas operasinya dengan mempertimbangkan tingkat perputaran persediaan dalam satu periode. Horngren et al (2003) menyatakan hubungan perputaran persediaan dengan profitabilitas yaitu perputaran persediaan mengukur kecepatan rata-rata persediaan bergerak keluar dari perusahaan. Semakin cepat persediaan dirubah menjadi barang dagang yang nantinya akan dijual oleh perusahaan maka akan semakin tinggi pula tingkat profitabilitasnya. Semakin tinggi tingkat profitabilitas yang dihasilkan oleh perusahaan maka akan semakin baik bagi kelangsungan hidup perusahaan tersebut.

\section{Penelitian Terdahulu}

Maridka (2012) membuktikan bahwa secara simultan perputaran persediaan dan arus kas (arus kas operasi) berpengaruh signifikan terhadap profitabilitas (ROA). Gunarto (2007) 
menemukan hubungan perputaran persediaan berpengaruh positif terhadap rasio laba. Herliana $d k k$ (2013) Perputaran persediaan berpengaruh positif terhadap harga pokok penjualan dan jumlah persediaan. Yasmani $d k k$ (2012) menemukan bahwa tingkat perputaran persediaan barang pada CV. Surya Jaya juga tidak memuaskan karena masih jauh dari standar yang ditetapkan perusahaan.

\section{Hipotesis Penelitian}

Ho: Perputaran persediaan voucher SEV berpengaruh negatif dalam meningkatkan laba operasi PT Elkomindo Mitra Nusantara Bengkulu.

Ha: Perputaran persediaan voucher SEV berpengaruh positif dalam meningkatkan laba operasi PT Elkomindo Mitra Nusantara Bengkulu.

\section{HASIL DAN PEMBAHASAN}

PT. Elkomindo Mitra Nusantara didirikan di Jakarta pada bulan September 2004 oleh ibu Mulyanti, Bapak Freddy Chandra dan Bapak Bambang. Kegiatan operasionalnya sehari-hari yang baru di mulai sebulan setalah pendiriannya yaitu bulan Oktober 2004, PT. Elkomindo Mitra Nusantara pada saat itu memang belum begitu besar dengan jumlah karyawan kurang lebih dari 15 (lima belas) orang. Pada tahun 2005 PT. Elkomindo Mitra Nusantara menjalin kerjasama dengan PT. Indosat, Tbk Untuk menjadi Distributor resmi yang bergerak dibidang penjualan produk Indosat khusus seluruh area Sumatera. Misi dari PT. Elkomindo Mitra Nusantara ini adalah menjadi 'Multi National Dealer.

Pada tahun 2007 tepatnya pada tanggal 05 Oktober, PT. Elkomindo Mitra Nusantara akan memperluas wilayah kerjanya dengan membuka kantor cabang di Bengkulu yang beralamatkan di Jl. Soeprapto No. 19 Bengkulu di bawah kepemimpinan Ibu Herlina. Pada tahun 2010 PT. Elkomindo Mitra Nusantara pindah alamat ke jalan Flamboyan No. 30 Sekip Bengkulu di bawah kepemimpinan Bpk Riswan. Pada tahun 2011 terjadinya perubahan manajemen kepemimpinan di PT. Elkomindo Mitra Nusantara Bengkulu di pimpin oleh bpk Mardi Cipto sampai dengan sekarang dengan jumlah karyawan sebanyak 20 orang dengan wilayah kerja meliputi Kabupaten Bengkulu Utara, Kabupaten Bengkulu Selatan, Kabupaten Curup, Kabupaten Kepahiang dan Kabupaten Lebong. Sebagai distributor resmi dari produk-produk PT. Indosat, tbk, kantor cabang PT. Elkomindo Mitra Nusantara melayani para agen kartu seluler yang membeli voucher dan perdana baik dalam jumlah partai kecil (eceran), maupun partai besar (grosiran).

PT. Elkomindo Mitra Nusantara merupakan distributor resmi dari PT. Indosat, Tbk yang bergerak dibidang penjualan produk Indosat meliputi penjualan voucher elektrik Indosat, voucher fisik, kartu perdana Indosat (Mentari, IM3, Starone). PT Indosat Tbk merupakan perusahaan telekomunikasi yang didirikan oleh Pemerintah pada tanggal 20 November 1967 sebagai sebuah perusahaan investasi asing untuk menyediakan jasa telekomunikasi internasional di Indonesia dan mulai beroperasi secara komersial pada bulan September 1969 untuk membangun, mentransfer dan mengoperasikan satelit organisasi Telekomunikasi Internasional (Intelsat), stasiun bumi di Indonesia untuk mengakses satelit Intelsat India Wilayah Samudra untuk jangka waktu 20 tahun. Sebagai sebuah konsorsium global komunikasi internasional organisasi satelit, Intelsat memiliki dan mengoperasikan sejumlah satelit telekomunikasi.

\section{Tabel 1. Rata-rata persediaan voucher SEV PT Elkomindo Mitra Nusantara}

\begin{tabular}{|l|r|r|r|r|r|r|}
\hline \multicolumn{2}{|l}{ No. Tahun } & \multicolumn{1}{c}{$\begin{array}{c}\text { Persediaan } \\
\text { awal }\end{array}$} & \multicolumn{1}{c}{$\begin{array}{c}\text { Persediaan } \\
\text { akhir }\end{array}$} & $\begin{array}{l}\text { Rata-rata } \\
\text { Persediaan } \\
\text { (Rp) }(\mathrm{a}+\mathrm{b}) / 2\end{array}$ & Pembelian \\
\hline 1 & 2011 & $1,050,160,000$ & $845,000,000$ & $1,472,660,000$ & $1,549,000,000$ & $1,754,160,000$ \\
\hline 2 & 2012 & $965,350,000$ & $1,059,250,000$ & $1,494,975,000$ & $1,654,000,000$ & $1,560,100,000$ \\
\hline 3 & 2013 & $1,475,500,000$ & $1,335,000,000$ & $2,143,000,000$ & $2,990.400,000$ & $3,130,900,000$ \\
\hline
\end{tabular}


Tabel di atas menunjukkan bahwa harga pokok penjualan voucher SEV PT. Elkomindo Mitra Nusantara pada tahun 2010 sebesar Rp. 1.754.160.000, tahun 2012 mengalami penurunan sebesar RP. 1.560.100.000 dan tahun 2013 mengalami peningkatan harga pokok penjualan sebesar Rp. 3.130.900.000.

Tabel 2. Tingkat perputaran persediaan voucher SEV PT Elkomindo Mitra Nusantara

\begin{tabular}{|c|l|l|c|c|c|} 
No. & Tahun & Laba operasi (Rp) & Penjualan (Rp) & $\begin{array}{c}\text { Persentase laba } \\
\text { operasi }\end{array}$ & $\begin{array}{c}\text { Perputaran } \\
\text { persediaan }\end{array}$ \\
\hline 1 & 2011 & $2,250,000,000$ & $21,000,000,000$ & $10,71 \%$ & 1,19 \\
\hline 2 & 2012 & $3,360,000,000$ & $28,000,000,000$ & $12,00 \%$ & 1,24 \\
\hline 3 & 2013 & $3,907,200,000$ & $32,560,000,000$ & $18,99 \%$ & 1,46 \\
\hline & & & & & 4,00 \\
\hline
\end{tabular}

Berdasarkan perhitungan di atas menunjukkan bahwa perputaran persediaan tahun 2011 adalah 1,19. Tahun 2012 mengalami peningkatan perputaran persediaan sebesar 1,24 dan tahun 2013 mengalami peningkatan sebesar 1,46. Ini menunjukkan bahawa semakin besar angka perputaran persediaan menjadi semakin baik yang berarti dalam penyediaan persediaan perusahaan sudah dilakukan secara efektif dan efisien. Analisis persentase laba yang telah diperhitungkan mengalami kenaikan dari tahun 2011 sebesar 10,71\%, tahun 2012 sebesar $12,00 \%$ dan 2013 sebesar 18,99.

Total perputaran persediaan terhadap persentase laba tahun 2011, 2012 dan 2013 sebesat 4,00 ini menunjukkan bahwa semakin besar laba maka perputaran persediaan terhadap laba semakin meningkat.

\section{Koefisien korelasi}

\begin{tabular}{|c|c|c|c|c|c|}
\hline No. & $\mathrm{X}$ & $\mathrm{Y}$ & $\mathrm{X} 2$ & $\mathrm{Y} 2$ & $\mathrm{XY}$ \\
\hline 1 & 1.19 & 10,71 & 1.42 & 114.80 & 12.76 \\
\hline 2 & 1.04 & 12.00 & 1.09 & 144.00 & 12.52 \\
\hline 3 & 1.46 & 13.17 & 2.13 & 173.52 & 19.25 \\
\hline & 3.70 & 35.89 & 4.64 & 432.32 & 44.53 \\
\hline
\end{tabular}

1. Analisis korelasi pearson product moment

$$
\begin{aligned}
& r=\frac{n \cdot \sum x y-\left(\sum x\right)\left(\sum y\right)}{\sqrt{n \sum x^{2}-\left(\sum x\right)^{2}} \sqrt{n \sum y^{2}-\left(\sum y\right)^{2}}} \\
& r=\frac{3 \times 44.53-(3.70)(35.89)}{\sqrt{\left.3 \times 4.64-(4.64)^{2} \sqrt{3 x 432.32^{2}-(432.32}\right)^{2}}} \\
& r=0.011
\end{aligned}
$$

2. Uji signifikan (Uji t)

$$
\begin{aligned}
& \mathrm{t}=\frac{\frac{r \sqrt{x}-2}{1-(x)^{2}}}{\mathrm{t}=}=\frac{0.211 \sqrt{3}-2}{1-(0.011)^{2}}
\end{aligned}
$$

$\mathrm{t}=\underline{0.011}$

0.999 


\section{$\mathrm{t}=0.011$}

Berdasarkan hasil analisis korelasi pearson product moment dengan tingkat signifikansi $(\alpha)$ $=0.05$, dengan $r_{\text {hitung }} 0.01<r_{\text {tabel }}(0.997)$ dan hasil uji $t=0.001$ ini membuktikan bahwa perputaran persediaan voucher SEV berpengaruh positif dalam meningkatkan laba operasi PT. Elkomindo Mitrra Nusantara Bengkulu.

\section{Kesimpulan}

Analisis perputaran persediaan dari tahun 2011, 2012, 2013 mengalami kenaikkan 4,00 dengan rincian tahun 2011 perputaran persediaan sebesar 1,19. Tahun 2012 perputaran persediaan sebesar 1,24 dan tahun 2013 mengalami peningkatan sebesar 1,46 yang menunjukkan bahwa semakin besar angka perputaran persediaan menjadi semakin baik yang berarti persediaan perusahaan sudah dilakukan secara efektif dan efisien dalam memenuhi permintaan pelanggan. Secara parsial bahwa perputaran persediaan berpengaruh terhadap peningkatan laba operasi perusahaan.

\section{Saran}

Persentase laba operasi PT. Elkomindo Mitra Nusantara masih mengalami fluktuasi walaupun analisa laporan keuangan menunjukkan perhitungan laba operasi tidak pernah mengalami kerugian, sehingga perusahaan perlu memperhatkan penggunaan biaya operasional yang mempunyai pengaruh. Usaha yang harus dilakukan untuk menaikkan penjualan yaitu jangan menambah biaya operasi yang terlalu tinggi dan meningkatkan efisiensi biaya operasi karena sangat mempengaruhi kemampuan perusahaan dalam memperoleh laba operasi yang maksimal. Memaksimalkan nilai perputaran persediaan dan meminimalkan jumlah hari penjualan dalam persediaan. Perusahaan harus lebih efisien memanfaatkan aktiva yang dimiliki dalam kegiatan operasionalnya untuk meningkatkan pendapatan atau meningkatkan laba bersih.

\section{DAFTAR PUSTAKA}

Alexandri, Moh. Benny. (2009). Manajemen Keuangan Bisnis Teori dan Soal. Bandung. Penerbit Alfabeta.

Baridwan, Zaki. (2004). Intermediate Accounting, Edisi Kedelapan, Cetakan Pertama, BPFE UGM, Yogyakarta.

Bambang, Riyanto. (2001). Dasar-Dasar Pembelanjaan Perusahaan. Yogyakarta. BPFE UGM.

Gade,Muhammad dan Said Khaerul Wasif. (2005). Akuntansi Keuangan Menengah 1, Edisi Kedua. Fakultas Ekonomi Universitas Indonesia, Jakarta.

Gunarto. 2007. Pengaruh Tingkat Perputaran Piutang dan Tingkat Perputaran Persediaan Terhadap Rentabilitas Ekonomi Pada KPRI Di Kabupaten Kudus Tahun 20042006. Skripsi. Semarang: Fakultas Ekonomi Universitas Negeri Semarang

Harahap, Sofyan Syafrie. 2011. Analisis Kritis atas Laporan Keuangan, Edisi 1-5, PT. Raja Grafindo Persada, Jakarta.

Herliana, Novriadi, K., Wahyuni, Trena (2013). Analisis Pengaruh Perputaran Persediaan Bahan Baku Terhadap Laba Perusahaan pada PT. Almi Caterindo Palembang. Fakultas Ekonomi Universitas Politeknik PalComTech Palembang. 
Horngren, Charles T et al. (2003). Pengantar Akuntansi Keuangan, Edisi Kedelapan, Jilid Ketiga, Erlangga, Jakarta.

Ikatan Akuntansi Indonesia (2009), Pernyataan Standar Akuntansi Keuangan, Jakarta : Salemba Empat.

Jumingan. (2008). Analisis Laporan Keuangan. Cetakan Pertama. Jakarta. PT. Bumi Aksara.

Jusup, Al Haryono. (2005). Dasar-Dasar Akuntansi, Jilid 2, Penerbit STIE YKPN, Yogyakarta.

Kuswadi. (2008). Memahami Rasio-rasio Keuangan Bagi Orang Awam,PT. Elex Media Komputindo, Jakarta.

K.R. Subramanyam \& John J. Wild, 2005, Financial Statement Analysis International Edition10th.McGraw-Hill.

Libby, Robert, Libby, Patricia A \& Short Daniel G. (2008). Akuntansi Keuangan. Diterjemahkan J.Agung Seputro. Yogyakarta : Penerbit Andi.

Munawir, S. (2002). Analisis Informasi Keuangan. Yogyakarta : Liberty

Munandar. (2011). Pokok-pokok Intermediate Accounting,Universitas Gajah Mada, Yogyakarta

Ristono, Agus. (2009). Manajemen Persediaan Edisi 1. Jakarta : Graham Ilmu.

Stice, James D \& Earl K. Stice (2009). Akuntansi Keuangan. Jakarta : Salemba Empat.

Soemarso. 2004. Akuntansi Suatu Penghantar Edisi 5 Buku 2. Jakarta : Salemba Empat.

Van Horne, James C \& John M. Wachowicz, JR. (2009). Prinsip - Prinsip Manajemen Keuangan. Jakarta: Salemba Empat

Yasmani, M., Kusuwardani, Anisa, Ikbal, M. (2012). Analisis Perputaran Piutang Dagang dan Persediaan Barang Dagangan pada CV. Surya Jaya. Skripsi Fakultas Ekonomi Universitas Mulawarwan. 